\title{
Metalinguistic Reflection and Computer-Mediated Communication: An Interventionist approach to Language Study Abroad
}

\author{
Meredith McGregor \\ Western University
}

\begin{abstract}
This article reports on part of a mixed-methods study framed by sociocultural theory and aimed at assessing the impact of an intervention to promote metalinguistic awareness in language study abroad sojourners. Participants utilized a social media platform as a space to develop personalized e-portfolios for the purpose of in-depth metalinguistic reflection, paired with entirely computer-mediated researcher-participant mentoring. As such, this study addresses the importance of intervention in second language learning in study abroad, while also adding to the research available on its intersections within a 24/7 digitally connected world. Analysis of the data suggests that carrying out reflective practices and engaging with a mentor, even at distance, may be contributory in enhancing Spanish language proficiency. Further, this provides evidence that interventionist approaches to study abroad can be made accessible and meaningful even in the absence of significant resources, and without implementing prohibitively onerous tasks for either a student or practitioner.
\end{abstract}

\section{Résumé}

Cet article rend compte d'une partie d'une étude de méthodes mixtes, encadrée par la théorie socioculturelle, dont l'objectif était d'évaluer l'impact d'une intervention visant à promouvoir la conscience métalinguistique chez les apprenants en séjour linguistique à l'étranger. Les participants ont utilisé une plateforme de médias sociaux comme espace pour développer des e-portfolios personnalisés dans le but d'approfondir la réflexion métalinguistique, associée à un mentorat chercheur-participant entièrement assisté par ordinateur. En tant que telle, cette étude traite de l'importance de l'intervention dans l'apprentissage d'une langue seconde lors d'un séjour d'études à l'étranger, tout en ajoutant à la recherche disponible sur ses intersections dans un monde connecté numériquement 24 heures sur 24, 7 jours sur 7 . L'analyse des données suggère que la mise en œuvre de pratiques de réflexion et l'engagement avec un mentor, même à distance, peuvent contribuer à améliorer la maîtrise de la langue espagnole. En outre, cela prouve que les approches interventionnistes des études à l'étranger peuvent être rendues accessibles et significatives même en l'absence de ressources importantes, et sans mettre en œuvre des tâches trop coûteuses pour un étudiant ou un praticien. 


\section{Metalinguistic Reflection and Computer-Mediated Communication: An Interventionist approach to Language Study Abroad}

Study abroad imagined as a transformative and fully immersive context for language learning is a compelling narrative and one that has long been mythologized. Students who choose to study a foreign language abroad often do so with the intention of immersing themselves in the language and learning in ways not thought possible in their home community or within the confines of a traditional classroom. Unfortunately, students are typically left to their own devices with little sociolinguistic preparation for their endeavors, and this makes for an incomplete learning experience. Simply being immersed in a speech community is not a guarantee that these students are acquiring linguistic competencies in line with the expectations of their institutions or the expectations they have for themselves, and this is truly doing a disservice to these students by not providing them with more structured support. It is a missed opportunity to guide them through what can be a rich and deeply formative experience and one that can elevate language learners to a higher level of awareness of their learning processes. Ideally, students would be provided with an occasion to prepare well in advance of their language study abroad, have access to expert guidance throughout their sojourns to promote the metalinguistic awareness necessary to examine their experiences critically, and to follow up their time abroad with in-depth reflection and further study (see DuFon \& Churchill, 2006; Jackson, 2008; Kinginger, 2011; Pellegrino Aveni, 2005; Pérez Vidal, 2014 for related recommendations).

While this comprehensive interventionist approach is one that requires resources that may or may not be available to university departments, there are ways that it can be made accessible. It is worth the investment to work with students and offer them a framework upon which to build their metalinguistic faculties so that they can make the most of the language learning opportunities presented to them. Without this, we are conceding to the myth that language learning is something effortless that automatically happens to a person while studying abroad. In fact, variability tends to be the rule rather than the exception in language gain (Anderson, 2014; Baker-Smemoe, Dewey, Bown, \& Martinsen, 2014; DeKeyser, 2010; George, 2014; Grey, Cox, Serafini, \& Sanz, 2015; Magnan \& Back, 2007, among others) due to a number of influential and individual factors. To this end, this study looks at the efficacy of an intervention during a semester abroad carried out via digital communication tools that are open-source and easily accessible, and its impact on language proficiency. Participants carried out meaningful, but not onerous, reflective tasks through a participant-managed, interactive e-portfolio, and worked with a mentor for the purpose of engaging in defining, supportive conversations throughout the semester.

\section{Literature review}

This study is based on the hypothesis that intervention to guide sojourners in their language study abroad, while not frequently employed in language study abroad programming, is a practice that has the potential to be highly impactful to the learning process. To date, research on intervention in study abroad has focused primarily on the acquisition of intercultural competencies (Bathurst \& La Brack, 2012; Doctor \& Montgomery, 2010; Engle \& Engle, 2004; Hemming Lou \& Bosley, 2008; Pedersen, 2010; 
Vande Berg, Quinn \& Menyhart, 2012). However, there has been some noteworthy work carried out on intervention to specifically support the acquisition of language skills in study abroad, namely the on-going research within the Center for Advanced Research on Language Acquisition (CARLA) at the University of Minnesota and their Maximizing Study Abroad (MAXSA) project (Paige, Cohen, Kappler, Chi, \& Lassegard, 2002). Additionally, the Georgetown Consortium Project (Vande Berg, Connor-Linton, Paige, 2009) at Georgetown University has also demonstrated the influence of mentoring for both intercultural and linguistic gain.

Following a socio-constructivist approach, the intervention in this study is based on Vygotsky's sociocultural theory, which suggests that more can be achieved when working with another person to make sense of the input and consolidate understanding. This is referred to by Vygotsky (1978) as the Zone of Proximal Development. This approach, whereby an expert mentor, instructor, or facilitator is positioned to initiate, and support sustained, in-depth, dialogic (van Compernolle, 2014) reflection throughout the study abroad experience has been used effectively in virtually all of the aforementioned interventionist studies (as well as Henery, 2014). It is frequently cited as one of the most influential and meaningful components of the interventionist approach, accounting for greater progress than any other type of intervention in both intercultural and metacognitive advancement.

Further, this study is framed within a modern study abroad context. In other words, it acknowledges the trajectory of study abroad concurrent to the rise of social media and digital connectedness, and its impact on the experiences of sojourners today. The role digital technologies play in the lives of most sojourners is significant, making study abroad qualitatively different than it was even two decades ago. The ability to retrieve information and engage in communicative practices via the Internet is (almost) at all times the mainstay within the consciousness of those who participate in wired societies, as was the case for the participants of this study. This can represent a distraction from the immersive opportunities presented (see Seibert Hanson, \& Dracos, 2016, research on higher motivation levels and a correlation with greater linguistic gains and less technology use), and even though students are warned of the consequences of remaining too digitally connected, it's ingenuous to expect them to forego on-going communications with their friends and family back home.

By extension of this, the current study attempted to leverage the affordances of digital technologies as integral to the intervention design, with the expectation that connected participants would be able and willing to access digital tools for the purpose of metalinguistic reflection. There are studies that have explored interventions in language study abroad, which have successfully incorporated some online components into their programming (Cohen \& Shively, 2007; Hemming Lou \& Bosley, 2008; Paige, Cohen, Kappler, Chi, \& Lassegard, 2003; Stewart, 2010; Vande Berg et al., 2012), some integrating digital tools more than others. Where the literature is less robust, is in the area of assessing more diversified methods of carrying out interventions via digital tools that permit students to reflect upon, document, and share their study abroad experiences within the dynamic Web 2.0 forum, which allows user-generated content. One such tool, the eportfolio, has appeared only marginally in research on measuring learning outcomes (Rhodes, Chen, Watson, \& Garrison, 2014). A meta-analysis of the publications available on e-portfolios (Bryant \& Chittum, 2013) showed that the majority were not developed with specific theoretical frameworks (a similar pattern has been noted in research on digital 
technologies and language acquisition [Wang \& Vasquez, 2012]) or control groups for comparison. More relevant to the present study, only a small minority featured objectives specific to measuring or analyzing language acquisition. The Council of Europe has done pioneering work with the development of their European Language Portfolio (ELP), and the National Council of State Supervisors for Languages (NCSSL) has adopted a similar model in their LinguaFolio and Global Language Portfolio. However, this is a growing body of research that has not yet been explored fully, in particular from a North American

gaze. Previously, researchers have not had access to the type or amount of content that can be produced within e-portfolio spaces, so this is an area that represents what could be a revolutionary approach to exploring language development over time (Cummins \& Davesne, 2009, p.856). With growing access to online social media platforms that may be used to document and share experiences, e-portfolio research has more recently gained scholarly attention related to language learning (Barrot, 2016; Cheng \& Chau, 2009; Sharifi, Soleimani, \& Jafarigohar, 2017; Williams, Chan, \& Cheung, 2009).

Being digital, an e-portfolio can be accessed anywhere, at any time, as long as there is a computer or online connection, so it may be used flexibly. Furthermore, essential to sociocultural theory, e-portfolios afford the opportunity for in-depth reflection (Brandes \& Boskic, 2008; Lin, 2008; OKeeffe, 2012), especially enabling students to "recognize" one's "own learning" (Johnsen, 2012, p.147), that may be carried out through a variety of media. They provide learners "a space to construct a reflective narrative" (Ehiyazaryan-White, 2012, p. 184). In this way, learners are "co-constructors of assessment information" (Sanford, Hopper, \& Fisher, 2014, p.73), actively negotiating their learning and assessing their progress, a skill that contributes to more independent, committed (p.78), and sustained learning habits. Also, as Desmet, Miller, Griffin, and Balthazor (2008) point out, "reflection is both process and product" (p. 19). In developing an e-portfolio, a learner is in effect participating in a process of learning but can then also look back at it as an entity and explore the evolution of their learning experiences. In reviewing the literature, it is clear that there is significant room for research in the area of how e-portfolios and other outlets for facilitating reflective practices can serve as tools for concretely augmenting learner outcomes in language acquisition.

\section{The current study}

Drawing on part of a larger project, this article focuses on addressing the following research question: Does intervention to promote metalinguistic awareness during language study abroad have a significant effect on students' ability to acquire language competencies in study abroad, and if so, do any particular tendencies emerge? The working hypothesis for this research question was that yes, there would be evidence to suggest that intervention to promote metalinguistic awareness can have a significant effect on students' ability to acquire language competencies in study abroad.

\section{Participants}

The participants in this study were recruited from incoming international (nonnative Spanish speakers) students at a university in Central America in July of 2016. A total of 23 participants participated in this study to completion. Both the control group and 
experimental groups were made up of male and female participants, all born between the years 1986 and 1995. The control group was made up of primarily native speakers of German, as well as two native speakers of Czech and one native speaker of French. In the experimental group there were six native speakers of French and four native speakers of German. In terms of language repertoires, all control group participants and all experimental group participants reported competency in Spanish, as well as English, with varying proficiency, aside from their native languages. Some reported competency in a fourth language, and, among the participants in the control group, even fifth, sixth, and seventh languages. Of the control group participants, nine had previously spent time (of varying durations) in Spanish-speaking regions, as had six of the experimental group participants. Crucially, only three of the control group participants indicated that they had had any pre-departure study abroad training of any kind. In the experimental group, only two participants had been briefed on administrative processes, medical warnings, and/or culture shock. Full details about each participant group can be found in Table 1 and Table 2.

Table 1

Control group participants' general information

\begin{tabular}{|c|c|c|c|c|c|}
\hline ID No. & Gender & $\begin{array}{l}\text { Birth } \\
\text { Year }\end{array}$ & L1 & Other Languages & $\begin{array}{l}\text { Received Formal Pre- } \\
\text { SA Preparation }\end{array}$ \\
\hline UCR-4 & $\mathrm{F}$ & 1995 & German & Spanish, English & No \\
\hline UCR-7 & $\mathrm{F}$ & 1990 & German & Spanish, English & Cultural Workshop \\
\hline UCR-12 & $\mathrm{F}$ & 1993 & German & $\begin{array}{l}\text { Spanish, English, Sign Language, } \\
\text { French, Italian }\end{array}$ & No \\
\hline UCR-13 & $\mathrm{F}$ & 1995 & German & $\begin{array}{c}\text { Spanish, English, French, } \\
\text { Portuguese }\end{array}$ & No \\
\hline UCR-14 & $\mathrm{F}$ & 1986 & German & Spanish, English & No \\
\hline UCR-15 & $\mathrm{F}$ & 1992 & German & $\begin{array}{l}\text { Spanish, English, Portuguese, } \\
\text { Latin, Dutch, Turkish }\end{array}$ & No \\
\hline UCR-18 & M & 1993 & German & Spanish, English & No \\
\hline UCR-19 & $\mathrm{F}$ & 1994 & German & Spanish, English, Italian & No \\
\hline UCR-21 & $\mathrm{F}$ & 1995 & German & Spanish, English, Latin & No \\
\hline UCR-22 & $\mathrm{F}$ & 1994 & German & Spanish, English, French, Latin & SA Prep. Course \\
\hline UCR-23 & M & 1993 & Czech & Spanish, English, French & No \\
\hline UCR-25 & M & 1994 & Czech & Spanish, English & General Prep. \\
\hline UCR-27 & $\mathrm{F}$ & 1993 & French & Spanish, English & No \\
\hline
\end{tabular}


Table 2

Experimental group participants' general information

\begin{tabular}{|c|c|c|c|c|c|}
\hline ID No. & Gender & $\begin{array}{l}\text { Birth } \\
\text { Year }\end{array}$ & L1 & Other Languages: & $\begin{array}{c}\text { Received Formal Pre-SA } \\
\text { Preparation }\end{array}$ \\
\hline UCR-8 & $\mathrm{F}$ & 1997 & French & Spanish, English, Italian & No. \\
\hline UCR-9 & M & 1995 & French & Spanish, English & $\begin{array}{l}\text { Conference on admin./culture } \\
\text { shock }\end{array}$ \\
\hline UCR-10 & $\mathrm{F}$ & 1992 & German & Spanish, English, French & No \\
\hline UCR-11 & $\mathrm{F}$ & 1995 & French & Spanish, English, German & Medical warnings \\
\hline UCR-16 & M & 1992 & German & Spanish, English & No \\
\hline UCR-17 & $\mathrm{F}$ & 1995 & French & Spanish, English & No \\
\hline UCR-20 & M & 1994 & French & Spanish, English & No \\
\hline UCR-26 & $\mathrm{F}$ & 1988 & German & Spanish, English, Italian & No \\
\hline UCR-28 & M & 1995 & German & Spanish, English & No \\
\hline UCR-30 & M & 1996 & French & Spanish, English & No \\
\hline
\end{tabular}

\section{Sources of data}

Participants in the control group were only asked to complete what is referred to here as Part I of this study: filling out a language profile, completing a Spanish proficiency test at the beginning and end of their study abroad sojourns, and answering a final questionnaire. Participants in the experimental group were asked to complete Part I and Part II of the study. They completed everything the control group did, and also completed an e-portfolio via the online social network platform Google+, guided by a series of prompt questions for each e-portfolio entry, and participated in one-on-one mentoring sessions whereby the participants engaged with a researcher-mentor, via online communication, to discuss their e-portfolio entries and experiences living and studying in the host country. All interactions between the participants and the researcher-mentor took place online, via computer-mediated digital communications.

Spanish proficiency test and post-study abroad questionnaire. The Spanish proficiency test (provided to the researcher by Dr. Bruhn de Garavito and Dr. Montrul, who developed this unpublished test at McGill University in the 1990s), was drawn in part from the larger, internationally recognized Diplomas de Español como Lengua Extranjera (DELE) Spanish proficiency exam as well as from the Modern Language's Association (MLA) Spanish proficiency test. It includes two parts, with a total of 50 questions, all multiple choice. The test targets a range of Spanish language skills including general comprehension, vocabulary, verb tenses, prepositions, as well as more advanced questions involving use of 
the subjunctive. This test, which has been used in multiple studies (Bruhn de Garavito \& Valenzuela, 2008; Cuza \& Frank 2010; Duffield \& White, 1999; Montrul \& Slabakova, 2003, among others), holds up as a valid tool for participant Spanish proficiency assessment, and as such, was selected for use in the present study to measure participants' proficiency and test achievement. In addition to repeating the proficiency test at the end of the semester, participants were asked a series of questions regarding their experiences as international students studying abroad. These questions related to their living circumstances, communication back home, cultural reception, and overall experiences living in the host community. Participants were also asked to rate their Spanish proficiency gain in reading, writing, listening, speaking, and pragmatics on a scale of 1-5 and explain how they felt their Spanish skills had improved. Specific to the experimental group, participants were asked to comment on their perspectives on the use of an e-portfolio as a tool for learning and on the mentoring sessions they participated in.

E-portfolio. The experimental group participants were asked to develop an eportfolio throughout the duration of their semester abroad, documenting and reflecting upon their experiences with both learning Spanish and living in the host country as an international student. In this way, the objective was to construct both a progressive and reflective e-portfolio eliciting participant observations and reflections. The platform chosen for the e-portfolio was Google's Google+. This platform was chosen for a number of reasons. It is open-source, freely accessible, and user-friendly. Also, it provides ease of access as part of the Google Suite, available on a computer or through its cellular device application, it has the potential for familiarity and repeated use among the participants (Levy, 2009), and it allows for dynamism as a tool permitting multi-media output. While Google is certainly not the only company that allows users to post and share via a portfoliolike platform (arguably Facebook, Twitter, and other social-networking sites can act as tools to do the same), many people are familiar with the Google brand, and it presented a high-quality product that was slightly lesser-known compared to the usual socialnetworking sites frequented by so many people. Therefore, it provided a space for participants to explore their study abroad experiences without feeling as though it would impede or somehow be connected to their personal and social interactions.

To guide their reflections, participants were provided with tasks including prompt questions they could answer in their different posts. The first task was to think about 3 SMART (specific, measurable, achievable, relevant, and time-based) goals for their semester to come, related to their language learning and study abroad experiences. The second task was to share a linguistic autobiography and discuss their language backgrounds and language learning experiences, including challenges they have faced in learning a language and approaches they have found work for them to acquire language skills. The third task was to discuss the linguistic landscapes around them (see Piller, 2011 on language and embedded ideologies) while living in the host country and studying at the host university. The fourth task asked participants to share a typical day in their lives as international students studying abroad, to discuss language use, interpersonal interaction, and other daily activities. The fifth and last task focused on the participants' communication in Spanish: aspects of the language they felt they could use with ease, as well as challenges and miscommunications they had experienced. 
Mentoring sessions. Mentoring has been shown to be the most salient contributing factor to intercultural competence gain and oral proficiency (Vande Berg, Connor-Linton, \& Paige, 2009). In this study, participants were asked to engage in discussions with a mentor regarding their study abroad experiences. This included discussing pragmatic aspects of language, participant identity as an international language study abroad student, and further discussing their e-portfolio contributions. Each participant engaged in a total of three semi-structured mentoring sessions during their semester abroad. During these sessions, the mentor provided the participants with several questions based on their e-portfolio reflections, and on linguistic and cultural observations they had made while living abroad. They were also asked questions intended to support them in navigating challenges they had faced in communicating in Spanish. Questions were about specific strategies they had employed in attempting to learn Spanish and gain more access to native Spanish speakers, as well as how they had approached pragmatic acts, such as making a complaint or responding to a compliment. The participants were, in turn, encouraged to ask questions that they had regarding any aspect of their learning process studying and living abroad. Participants asked questions related to the usage of certain linguistic forms such as the Spanish subjunctive and pronouns of address, as well as vernacular forms they had heard and were attempting to use among their Spanish-speaking peers. In some cases, participants were provided with further details on linguistic forms and rules of use as follow-up to their questions in an effort to support them in successfully applying the new forms in situ. What makes this mentoring model more innovative than previous studies in language acquisition in study abroad, is the leveraging of digital technologies to test their viability as tools that can effectively facilitate mentor-mentee engagement when combined with the above described reflective documentation via the eportfolio. Further, the emphasis on pragmatic decision-making and identity performance, as per the gaps in the literature highlighted by Kinginger (2013), widens the scope of how the interventionist approach is being tested.

\section{Results}

\section{Pre/post Spanish language proficiency tests}

The quantitative results from the proficiency testing at the outset of the semester showed no significant difference in the two groups' $(\mathrm{N}=23)$ scores. By the end of the semester, however, the statistical analyses revealed some significant differences.

Explanation of the proficiency test results will be broken down into three categories: Part I, out of a total of 30 points, Part II out of a possible 20 points, and the total test scores out of a possible 50 points.

In Part I of the test, the average control group $(n=13)$ score moved from 19.46 out of 30 or $64.86 \%(\mathrm{SD}=6.98)$ to 23.76 out of 30 or $79.2 \%(\mathrm{SD}=3.67)$. The average experimental group $(n=10)$ score moved from 20.3 out of 30 or $67.66 \%(\mathrm{SD}=5.75)$ to 26.0 out of 30 or $86.66 \%(\mathrm{SD}=3.19)$. This denotes a percentile increase of $14.34 \%$ in the control group and a $19.0 \%$ increase in the experimental group, a difference of $4.66 \%$ between the two groups. A summary of these scores can be seen in Table 3 . 
Table 3

Control/experimental groups' pre/post proficiency test performance - Part I

\begin{tabular}{lccccccc}
\hline \multicolumn{7}{c}{ Pre-Test } & \multicolumn{5}{c}{ Post-Test } \\
\hline & $\begin{array}{c}\text { Av. } \\
\text { Score } \\
130\end{array}$ & $\%$ & S.D. & $\begin{array}{c}\text { Av. } \\
\text { Score } \\
/ 30\end{array}$ & $\%$ & S.D. & $\%$ \\
& 19.46 & 64.8 & 6.98 & 23.76 & 79.2 & 3.67 & 14.34 \\
\hline $\begin{array}{l}\text { Control } \\
\text { Group }\end{array}$ & & 6 & & & & & \\
$\begin{array}{l}\text { Experimental } \\
\text { Group }\end{array}$ & 20.3 & $\begin{array}{c}67.6 \\
6\end{array}$ & 5.75 & 26.0 & 86.66 & 3.19 & 19.0 \\
& & 6 & & & & &
\end{tabular}

In Part II of the test, the average control group score moved from 10.84 or $54.2 \%$ $(\mathrm{SD}=3.21)$ down to 10.46 or $52.3 \%(\mathrm{SD}=2.25)$ out of 20 , and the average experimental group score in Part II moved from 10.8 or $54 \%(\mathrm{SD}=2.89)$ to 12.6 or $63 \%(\mathrm{SD}=3.06)$. This denotes a percentile decrease of $1.9 \%$ in the control group and an increase of $9 \%$ in the experimental group, a difference of $7.1 \%$. A summary of these scores can be seen in Table 4.

Table 4

Control/experimental groups' pre/post proficiency pest performance - Part II Pre-Test Post-Test

\begin{tabular}{lccccccc}
\hline & $\begin{array}{c}\text { Av. } \\
\text { Score } \\
120\end{array}$ & $\%$ & S.D. & $\begin{array}{c}\text { Av. } \\
\text { Score } \\
/ 20\end{array}$ & $\%$ & S.D. & $\begin{array}{c}\% \\
\text { Change }\end{array}$ \\
\hline $\begin{array}{l}\text { Control } \\
\text { Group }\end{array}$ & 10.84 & $\begin{array}{c}54 . \\
2\end{array}$ & 3.21 & 10.46 & 52.3 & 2.25 & -1.9 \\
$\begin{array}{l}\text { Experimental } \\
\text { Group }\end{array}$ & 10.8 & $\begin{array}{c}54 . \\
0\end{array}$ & 2.89 & 12.6 & 63.0 & 3.06 & +9.0 \\
& & 0 & & & & &
\end{tabular}

For the overall test, the average control group score moved from 30.30 or $60.6 \%$ $(\mathrm{SD}=9.49)$ to 34.23 or $68.46 \%(\mathrm{SD}=5.27)$ out of 50 , and the average experimental group score moved from 31.1 or $62.2 \%(\mathrm{SD}=8.04)$ to 38.6 or $79.2 \%(\mathrm{SD}=5.31)$. This denotes a percentile increase of $7.86 \%$ in the control group and an increase of $14.92 \%$ in the experimental group, a difference of $7.06 \%$. These overall average mean scores for the control group and the experimental group can be seen in Table 5. 
Table 5

Control/experimental groups' pre/post proficiency test performance - Overall scores

Pre-Test

Post-Test

\begin{tabular}{lccccccc}
\hline & $\begin{array}{c}\text { Av. } \\
\text { Score } \\
150\end{array}$ & $\%$ & S.D. & $\begin{array}{c}\text { Av. } \\
\text { Score } \\
/ 50\end{array}$ & $\%$ & S.D. & $\begin{array}{c}\% \\
\text { Increase }\end{array}$ \\
\hline $\begin{array}{l}\text { Control } \\
\text { Group }\end{array}$ & 30.30 & $\begin{array}{c}60 . \\
6\end{array}$ & 9.49 & 34.23 & 68.46 & 5.27 & 7.86 \\
$\begin{array}{l}\text { Experimental } \\
\text { Group }\end{array}$ & 31.1 & $\begin{array}{c}62 . \\
2\end{array}$ & 8.04 & 38.6 & 79.2 & 5.31 & 14.92 \\
\hline
\end{tabular}

A series of independent samples and paired samples $t$-tests were conducted to see if the two groups differed significantly in their scores for the pre-test and post-test. In interpreting the results of the statistical analyses, I considered not only significant results that emerged, but also those approaching significance, noting that both offer interesting findings that either support the hypotheses in this study or indicate trends that could be explored further in future research. It is worth noting, however, that no Bonferroni corrections were made in any of the following analyses. In comparing the pre-sojourn test scores between the two groups, no significant results were found for Part I of the test, $p=$ 0.762 , Part II of the test, $p=0.972$, or total test, $p=0.835$. This suggests that the two groups performed similarly at the outset of the study, a desirable starting point. There was not a significant difference between the scores of the control group and those of the experimental group in the post-sojourn test either in Part I of the test, $p=0.142$. However, for Part II of the test and in comparing the overall scores, there was an apparent difference approaching statistical significance: $p=0.067$ and $p=0.063$, respectively.

Table 6

Between group analyses of pre/post proficiency tests - Part I, Part II, and Overall scores

Part I Part II Overall

\begin{tabular}{lccc}
\hline Pre-Test & $p=0.762$ & $p=0.972$ & $p=0.835$ \\
\hline Post-Test & $p=0.142$ & $p=0.067$ & $p=0.063$
\end{tabular}

Following the between-group analyses, within-group analyses were conducted to compare the pre/post-sojourn test scores for each individual group. The control group's scores in Part I of the test showed a statistically significant difference between the presojourn and post-sojourn tests: $p=0.003$. Similarly, a significant difference was observed between the pre-test and post-test for the total score, $p=0.026$. However, for Part II of the test, there was no significant difference between the pre-test and the post-test: $p=0.648$. This suggests that the control group did not demonstrate significant change in its responses 
in the second, more advanced part of the proficiency test. Conversely, for the experimental group, there were statistically significant differences between the pre-test and the post-test for all three measures: in Part I, $p=0.004$, in Part II, $p=0.048$, and in the total test scores, $p=0.002$. Thus, while the within-group pre-post-sojourn analyses for the control group did not show a significant difference in test scores in Part II of the proficiency test, those of the experimental group did. This indicates that participants in the experimental group were able to advance their Spanish language proficiency on the most challenging aspect of the test while those within the control group were not.

Table 7

Within group analyses of pre/post proficiency tests - Part I, Part II, and Overall scores Part I Part II Overall

\begin{tabular}{lccc}
\hline Control Group & $p=0.003$ & $p=0.648$ & $p=0.026$ \\
Experimental & $p=0.004$ & $p=0.048$ & $p=0.002$ \\
Group & &
\end{tabular}

\section{Reported Spanish Proficiency Improvement}

The reported post-sojourn Spanish proficiency improvement data from the postsojourn questionnaire shows some variability across the participant groups. As Table 8 shows, on the whole, the control group rated their improvement in the four skills (reading, writing, listening, and speaking) on a scale of 1 to 5 (with 5 being the highest improvement) higher than the experimental group participants. In terms of individual categories, the control group reported more improvement in reading $(M=3.69, S D=1.03)$, writing $(M=3.62, S D=0.87)$, and speaking $(M=3.69, S D=0.85)$ skills compared to the experimental group, in which $M=3.4(S D=1.07), M=3.5(S D=0.77)$, and $M=3.3(S D=$ $0.82)$ respectively. The only skill for which the experimental group reported more improvement than the control group was listening. The control group mean for listening was $3.77(S D=1.01)$ and for the experimental group, it was $3.9(S D=0.74)$. From the data described in the previous section, it is clear that, while test results did not show greater improvement in the control group compared to the experimental group, self-reports by participants suggest that the control group did progress more. In particular, it is of value to look at the reported improvement in the skill of reading, as it is one skill that is heavily represented in the proficiency test. Independent samples t-tests comparing the responses of the control group with those of the experimental group showed no significant difference in any of the reported skills improvement data: Reading $p=0.515$, Writing $p=0.736$, Listening $p=0.735$, Speaking $p=0.280$ with a $95 \%$ confidence interval of difference containing zero in all cases; however, the above means indicate that there was some variance in the reported ratings with the control group perceiving their improvement to be slightly higher. 
Table 8

Control/experimental groups' reported Spanish proficiency improvement

\begin{tabular}{lccccc}
\hline & \multicolumn{2}{c}{ Control Group } & \multicolumn{2}{c}{ Experimental Group } & T-Test \\
\cline { 2 - 6 } \multicolumn{1}{c}{ Skill } & Mean & S.D. & Mean & S.D. & Sig. \\
\hline Reading & 3.69 & 1.03 & 3.4 & 1.07 & $p=.515$ \\
Writing & 3.62 & .87 & 3.5 & 0.77 & $p=.736$ \\
Listening & 3.77 & 1.01 & 3.9 & 0.74 & $p=.735$ \\
\hline Speaking & 3.69 & .85 & 3.3 & .82 & $p=.28$ \\
\hline
\end{tabular}

When the participants were asked to explain more precisely how their Spanish language skills had improved and to cite specific examples, some interesting insights emerged. This provided qualitative data to further expand upon the self-reported ratings, and it presented participants with an opportunity to describe specific experiences during their stays abroad that they felt had contributed to their linguistic gain. Generally, participants in the control group and experimental group responded differently to this question in that both groups highlighted specific skills they felt they had improved, but the control group provided considerably more detail about the reasons why. In terms of specific skills, neither group emphasized improvement in their discrete listening competences. Interestingly, as the reported Spanish proficiency improvement data shows (Table 8), the skill of listening was, on average, rated the highest for both the control group and the experimental group, so, in this regard, the quantitative and qualitative data differ. Some participants alluded to improved conversational practices, which naturally connotes a capacity for listening, so one can infer that the participants recognized a certain amount of gain in this respect. However, for both groups, most of the emphasis in their responses was on improved productive skills, namely speaking skills. The majority of participants in the control group explicitly noted their improved ability to speak in Spanish, with only one participant suggesting that they felt they had not improved their speaking skills significantly. Most of the participants in the control group also referenced writing as a key area of improvement, and vocabulary was mentioned twice. Within the experimental group, a majority of the participants noted an improvement in speaking, and half cited significant vocabulary gain, while only three participants noted an improvement in writing. It is also worth noting that two participants within the experimental group explicitly stated that they had not improved their Spanish language skills as much as expected. Overall, between the two groups, there was a sense of greater perceived Spanish language improvement from the control group participants in their qualitative responses, which was also reflected in their scaled ratings.

The responses from the control group participants regarding the reasons why they felt their Spanish language skills had improved were much more robust than those of the experimental group. The control group participants cited their academic studies at the university as being the most important factor in improving their language skills. They repeatedly referenced coursework, readings, essays, and other assignments as having had a 
positive impact on their language learning experiences. To a slightly lesser degree, the control group participants cited relationships and socializing outside of school as a key factor in their improvement. Additionally, three control group participants referenced activities of daily living (going to the store, casual interactions, etc.) as having had an impact on their language abilities. In contrast, only half of the experimental group participants provided details about why they felt they had improved. Within their responses, university studies and relationships with Spanish-speaking friends were cited as having influenced their progress in developing their Spanish language skills. The other half of the experimental participants only commented on the skills they felt they had improved, providing no further insights into experiences or behaviours they felt had contributed to their language gain.

\section{Discussion}

The data analysis comparing the participants' pre/post-sojourn proficiency test scores revealed some contrasting findings, with the experimental group outperforming the control group in key areas. The experimental group produced higher average scores in both parts of the test and in the overall test totals. Further, the experimental group demonstrated statistical significance in its test scores from the beginning to the end of the semester in Part II of the test, as well as the overall scores, compared to the control group. While there was no statistically significant difference between the two groups in their performance on Part I of the test, it is important to remember that this was the less challenging portion of the test. It stands to reason that the participants in this study would not demonstrate differential performance on Part I of the test, given their initial levels of Spanish and the potential for a learning plateau to take place (Brecht, Davidson \& Ginsberg, 1995; JuanGarau, 2014). Faced with subjunctive forms and prepositional phrases within the more advanced portion of the proficiency test, however, the experimental group seemed to outperform the control group. In comparing the control group's pre-test and post-test scores for Part II of the test, no statistically significant findings emerged, suggesting that their competence in the areas of Part II did not significantly change, which stands in contrast to the experimental group. Based on these findings, it is reasonable to suggest that intervention during language study abroad to promote metalinguistic awareness can have a significant impact on language gain. Ginsberg and Miller (2000) point out that a "nongainer effect" can present itself, even in immersive contexts such as language study abroad sojourns, and that this can be partially attributed to fewer opportunities for integrating theory and practice. Another study that looked specifically at the acquisition of the Spanish subjunctive found that formal instruction had a positive effect, in particular for learners who had previously participated in study abroad (Isabelli, 2007). These findings might help to explain some of the results in the current study. The experimental participants, who had the opportunity to reflect on their language learning and pose questions to an expert mentor over the course of the semester, may have better positioned to achieve greater gains in the more challenging parts of the proficiency test due to the support they received, combined with their experiences living and studying abroad. As the theoretical framework of this study suggests, a more knowledgeable other (Vygotsky, 1978), or a "mediator of meaning" (Daniels, 2016, p. 18) can assist the learner in assimilating new information and/or assigning meaning to their experiences, and perhaps 
this can, in part, explain the differing testing performance between the two groups and their ability to demonstrate competency in specific language forms.

Although not statistically significant, the experimental participants reported lower perceived improvement in their language skills at the end of the semester as compared to the control group, their test scores proved otherwise. When prompted to expand on how they had improved their language learning skills, however, the experimental group provided only minimal details, while participants in the control group were able to explain how they felt their Spanish language skills had improved and what in situ experiences had led to their perceived progress. Perhaps the control group participants, having not participated in Part II of the study, felt compelled to provide a more nuanced depiction of their language learning experiences compared to the experimental group participants given their different roles within the study. Alternatively, these findings may also be explained through a consideration of cognitive bias, specifically, the Dunning-Kruger Effect (Dunning, Johnson, Ehrlinger, \& Kruger, 2003; Kruger \& Dunning, 1999), or the idea that people who know less are more likely to make inflated judgements about their actual performance abilities. It is possible that the control group participants, having not received the treatment in this study, had accrued less expertise about their language skills and were, therefore, overconfident in their self-assessments and in isolating specific actions that led to their improvement. This is by no means conclusive, given the fact that the analyses on the self-reported improvement scores produced no statistically significant results. However, similar trends have been identified in studies comparing self-assessments to other, less subjective measures, including studies on a range of language skills (Summers, Cox, McMurry, \& Dewey, 2019; Trofimovich, Isaacs, Kennedy, Saito, \& Crowther, 2016, among others), so this is an area that may be worth exploring further in future research examining the efficacy of metalinguistic awareness and its impact on language learning.

\section{Conclusion}

The study described here was designed to build upon the empirical body of knowledge available on intervention in language study abroad and its impact on language proficiency while also deploying the use of digital technologies for the purpose of facilitating the main treatments of the study. There are a number of limitations to this study, probably the most obvious one being the fact that it features only a small group of participants. As an extension of that, this study examines the experiences of these individuals in one place, studying one language, during one semester abroad. The scenario is patently narrow, without the advantage of more voices over a longer duration of time. Further to that, given this study's requirement of voluntary participation, it is entirely possible that the self-selecting group of experimental participants was more amenable to the somewhat more onerous task of documenting and discussing their observations and learning experiences, therefore, positioning themselves as inherently more willing, active agents. Without a randomized sample, whether or not one group proved significantly different than the other based purely on the experimental treatment alone cannot be known.

Another limitation to this study, as it pertains to the sample groups, has to do with the inherent position of the privilege these participants enjoy. As university students, these individuals possess a level of education that most people in the world do not have access to. Additionally, given their status as international students and world travelers hailing 
from Western nations, they represent a cohort of people who carry passports that give them ready access to crossing international borders. In addition, as far as the researcher has been made aware, none of these individuals were studying abroad on scholarship funds, so given the fact that they had the means to travel and spend time abroad, naturally places them in the upper socioeconomic echelons of society. For these reasons and other factors associated with privilege and power, this study does, unfortunately, not deviate from the vast majority of study abroad research that has come before it in that the participants do not represent diverse populations of individuals of varying backgrounds. Study abroad in and of itself has historically been and continues to be an elitist endeavour, and this is reflected in the research to date. How individuals coming from differing social classes interpret study abroad experiences (Kinginger, 2008), for example, is one avenue that has not been explored in any great measure. In addition to that, Kinginger (2013) also notes that both race and sexuality are missing from the literature to date on SLA in study abroad (p.354). This is echoed by earlier work by Talburt \& Stewart (1999), who emphasize the need for more research into race relations and gender in study abroad participants. Therefore, there are many interesting and important areas to which research efforts have not devoted significant time or attention. Granted, more opportunities for individuals who represent minority groups and varied racial, ethnic, and religious backgrounds to participate in study abroad sojourns are needed so that empirical research may be conducted. Fortunately, the Journal of Blacks in Higher Education (2017) has reported an increased percentage of study abroad participation among African Americans in the 2015-2016 academic year compared to years passed. However, more emphasis should be placed on researching these variables and how they affect SLA as a strategy for promoting and enhancing study abroad programming for broader populations of people.

To conclude, there is utility to be derived from investing in sojourners during language study abroad. The results in this study demonstrate significant gains in the experimental group as compared to their control group counterparts, making a reasonably strong argument for a language study abroad model that is more holistic in its delivery. Although " $[\mathrm{t}]$ here is no best or single way to intervene" (Hemming Lou, Vande Berg, \& Paige, 2012, p.415), it seems fair to suggest that intervention of any kind is worth considering not only for the benefit of the individual language learner but also for the integrity of study abroad programming as a whole. In the case of this project, complementing the rich learning potential of living in an immersive environment with active participation in a reflection process with the support of an expert mentor, seems to offer the possibility of a linguistically formative experience, and can be done accessibly and cost-effectively without hampering the overall objective of language gain. Reforming and enhancing study abroad programming in this way can set the table for more engaged, metalinguistically aware participants who may be able to achieve more as language learners during their study abroad sojourns and beyond. Given the multitude of meaningful yet invisible ways one may be affected by a study abroad experience, "more" achievement is not necessarily the main objective of all sojourners or their home-based institutions; however, acquired knowledge about language and language proficiency are certainly among the expectations of spending time abroad, and because there exists a certain mythology surrounding perceived versus actual acquired linguistic competencies, more structured support is recommended. 
Correspondence should be addressed to Meredith McGregor.

Email: meredith.mcgregor@gmail.com

\section{References}

Anderson, S. L. (2014). Individual differences \& study abroad: Four profiles of oral proficiency gain. Journal of Language Teaching and Research, 5(3), 477-486. doi:10.4304/jltr.5.3.477-486

Baker-Smemoe, W., Dewey, D. P., Bown, J., \& Martinsen, R. A. (2014). Variables affecting L2 gains during study abroad. Foreign Language Annals, 47(3), 464-486. doi:10.1111/flan.12093

Barrot, J. S. (2016). Using facebook-based e-portfolio in ESL writing classrooms: Impact and challenges. Language, Culture and Curriculum, 29(3), 286-301. doi:10.1080/07908318.2016.1143481

Bathurst, L. \& La Brack B. (2012). Shifting the locus of intercultural learning: intervening prior to and after student experiences abroad. In M. Vande Berg, R. M. Paige \& Lou, K. H. (Eds.), Student Learning Abroad: What Our Students Are Learning, What They're Not, and What We Can Do About It (pp. 261-283). Sterling, VA: Stylus Publishing, LLC

Brandes, G. M., \& Boskic, N. (2008). Eportfolios: From description to analysis. The International Review of Research in Open and Distributed Learning, 9(2) doi:10.19173/irrodl.v9i2.502

Brecht, R.D., Davidson, D.E. \& Ginsberg, R.B. (1995). Predictors of foreign language gain during study abroad. In Barbara F. Freed (Ed.), Second Language Acquisition in a Study Abroad Context. pp. 37-66. Amsterdam, The Netherlands: John Benjamins, B.V.

Bruhn de Garavito, J., \& Valenzuela, E. (2008). Eventive and stative passives in Spanish L2 acquisition: a matter of aspect. Bilingualism: Language and Cognition, 11(3), 323-336.

Bryant, L. H., \& Chittum, J. R. (2013). Eportfolio effectiveness: A(n ill-fated) search for empirical evidence. International Journal of ePortfolio, 3(2), 189-198. Retrieved from http://www.theijep.com/pdf/IJEP108.pdf

Cheng, G., \& Chau, J. (2009). Digital video for fostering self-reflection in an ePortfolio environment. Learning, Media, and Technology, 34(4), 337-350. doi:10.1080/17439880903338614

Cohen, A. D., \& Shively, R. L. (2007). Acquisition of requests and apologies in Spanish and French: Impact of study abroad and strategy-building intervention. The Modern Language Journal, 91(2), 189-212. doi:10.1111/j.1540-4781.2007.00540.x

Cummins, P. W., \& Davesne, C. (2009). Using electronic portfolios for second language assessment. The Modern Language Journal, 93(1), 848-867. doi:10.1111/j.15404781.2009.00977.x

Cuza, A., \& Frank, J. (2010). The acquisition of double que questions in Heritage and L2 Spanish. Proceedings of the 2010 annual conference of the Canadian Linguistic Association/Actes du congrès annuel de l'Association canadienne de linguistique 2010.

Daniels, H. (2016). Vygotsky and Pedagogy. New York, NY: Routledge.

DeKeyser, R. (2010). Monitoring processes in Spanish as a second language during a 
study abroad program. Foreign Language Annals, 43(1), 80-92. doi:10.1111/j.19449720.2010.01061.x

Desmet, C., Miller, D., Griffin, J., \& Balthazor, R. (2008). Reflection, revision, and assessment in first-year composition ePortfolios. Journal of General Education, 57(1), 15-30.

DuFon, M., \& Churchill, E. (2006). Language learners in study abroad contexts / edited by Margaret A. DuFon and Eton Churchill. Clevedon, England ;: Multilingual Matters.

Doctor, M., \& Montgomery, L. (2010). Using IDI Guided Development to maximize the study abroad experience: A case study. Paper presented at the Second Intercultural Development Inventory Conference, Minneapolis, MN.

Duffield, N., \& White, L. (1999). Assessing L2 knowledge of Spanish clitic placement: convergent methodologies. Second Language Research, 15(2), 133-160.

Dunning, D., Johnson, K., Ehrlinger, J., \& Kruger, J. (2003). Why people fail to recognize their own incompetence. Current Directions in Psychological Science, 12, 83-87. doi:10.1111/1467-8721.01235

Ehiyazaryan-White, E. (2012). The dialogic potential of ePortfolios: Formative feedback and communities of learning within a personal learning environment. International Journal of ePortfolio, 2(2), 173-185.

Engle, L. \& Engle, J. (2004). Assessing language acquisition and intercultural sensitivity development in relation to study abroad program design. Frontiers: The Interdisciplinary Journal of Study Abroad, 10, 219-236.

George, A. (2014). Study abroad in central Spain: The development of regional phonological features. Foreign Language Annals, 47(1), 97114.doi:10.1111/flan.12065

Ginsberg, R. \& Miller, L. (2000). What do they do? Activities of students during study abroad. In R. Lambert and E. Shohamy (Eds.), Language policy and pedagogy: Essays in honor of A. Ronald Walton (pp. 237-260). Amsterdam: John Benjamins.

Grey, S., Cox, J. G., Serafini, E. J., \& Sanz, C. (2015). The role of individual differences in the study abroad context: Cognitive capacity and language development during Short-Term intensive language exposure. The Modern Language Journal, 99(1), 137-157. doi:10.1111/modl.12190

Hemming Lou, K. \& Bosley, G. W. (2008). Dynamics of cultural contexts: Meta-level intervention in the study abroad experience. In V. Savicki (Ed.), Developing intercultural competence and transformation (pp.276-296). Sterling, VA: Stylus.

Hemming Lou, K. \& Bosley, G. W. (2012). Facilitating intercultural learning abroad: The intentional, targeted intervention model. In M. Vande Berg, R. M. Paige \& Hemming Lou, K. (Eds.), Student Learning Abroad: What Our Students Are Learning, What They're Not, and What We Can Do About It (pp. 335-359). Sterling, VA: Stylus Publishing, LLC

Hemming Lou, K., Vande Berg, M., \& Paige, R. M. (Eds). (2012). Student Learning Abroad: What Our Students Are Learning, What They're Not, and What We Can Do About It. Sterling, VA: Stylus Publishing, LLC.

Henery, A. (2014). 'Interpreting 'real' French: The role of expert mediation in learners' observations, understandings, and use of pragmatic practices while abroad. Ph.D. diss., Carnegie Mellon University. 
Isabelli, C. A. (2007). Development of the spanish subjunctive by advanced learners: Study abroad followed by At-Home instruction. Foreign Language Annals, 40(2), 330341. doi:10.1111/j.1944-9720.2007.tb03205.x

Jackson, J. (2008). Language, Identity, and Study Abroad. Oakville, CT: DBBC

Johnsen, H. L. (2012). Making learning visible with ePortfolios: Coupling the right pedagogy with the right technology. International Journal of ePortfolio, 2(2), 139148.

Juan-Garau, M. (2014). Oral accuracy growth after formal instruction and study abroad. In C. Pérez-Vidal (Ed.), Language acquisition in study abroad and formal instruction contexts. (pp.87-109). Amsterdam, the Netherlands; Philadelphia, PA: John Benjamins Publishing Company.

The Journal of Blacks in Higher Education. (2017). African American presence among study abroad students continues to rise. Retrieved from www.jbhe.com/2017/12/african-american-presence-among-study-abroad-studentscontinues-to-rise/.

Kinginger, C. (2008). Language learning in study abroad: Case studies of Americans in France. Modern Language Journal, 92(1), 1-123. doi:10.1111/j.15404781.2008.00821.x

Kinginger, C. (2011). Enhancing language learning in study abroad. Annual Review of Applied Linguistics, 31(Mar), 58-73. doi:10.1017/S0267190511000031

Kinginger, C. (2013). Identity and language learning in study abroad. Foreign Language Annals, 46 (3), 339-358. doi:10.1111/flan.12037

Kruger, J., \& Dunning, D. (1999). Unskilled or unaware of it: Difficulties in recognizing one's own incompetence lead to inflated self-assessments. Journal of Personality and Social Psychology, 77, 1121-1134. doi:10.1037/0022-3514.77.6.1121

Levy, M. (2009). Technologies in use for second language learning. The Modern Language Journal, 93(1), 769-782. doi:10.1111/j.1540-4781.2009.00972.x

Lin, Q. (2008). Preservice teachers' learning experiences of constructing e-portfolios online. Internet and Higher Education, 11, 194-200.

Magnan, S. S., \& Back, M. (2007). Social interaction and linguistic gain during study abroad. Foreign Language Annals, 40(1), 43-61. doi:10.1111/j.19449720.2007.tb02853.x

Montrul, S., \& Slabakova, R. (2003). Competence similarities between native and near-native speakers. Studies in Second Language Acquisition, 25, 351-398.

OKeeffe, M. (2012). Exploring supports provided for ePortfolio development in a professional development context. Articles. Paper 9. Retrieved February 27, 2013, from http://arrow.dit.ie/libart

Paige, R. M., Cohen, A. D., Kappler, B., Chi, J.C., \& Lassegard, J. P. (2002). Maximiz-ing study abroad: A students' guide to strategies for language and culture learning and use, Minneapolis, MN: Center for Advanced Research on Language Acquisition, University of Minnesota.

Pedersen, P. J. (2010). Assessing intercultural effectiveness outcomes in a year long study abroad program. The International Journal of Intercultural Relations, 34, 70-80.

Pellegrino Aveni, V. (2005). Study Abroad and Second Language Use: Constructing the Self. New York, NY: Cambridge University Press, p. 8-33.

Pérez Vidal, C. (2014). Language acquisition in study abroad and formal instruction 
contexts. Amsterdam, the Netherlands; Philadelphia, PA;: John Benjamins

Publishing Company.

Piller, I. (2011). Intercultural communication: A critical introduction. Edinburgh: Edinburgh University Press.

Sanford, K., Hopper, T., \& Fisher, P. (2014). Changing paradigms: Embracing contemporary learning theories through e-portfolios. In K. Sanford \& T. StrongWilson (Eds.). The emperor's new clothes?: issues and alternatives in uses of the portfolio in teacher education programs. New York: Peter Lang.

Seibert Hanson, A. E. \& Dracos, M. J. (2016). Motivation and technology use during second-language study abroad in the digital age. Canadian Journal of Applied Linguistics, 19(2), 64-84.

Sharifi, M., Soleimani, H., \& Jafarigohar, M. (2017). E-portfolio evaluation and vocabulary learning: Moving from pedagogy to andragogy. British Journal of Educational Technology, 48(6), 1441-1450. doi:10.1111/bjet.12479

Stewart, J. (2010). Using e-journals to assess students' language awareness and social identity during study abroad. Foreign Language Annals, 43(1), 138-159. doi:10.1111/j.1944-9720.2010.01064.X

Summers, M. M., Cox, T. L., McMurry, B. L., \& Dewey, D. P. (2019). Investigating the use of the ACTFL can-do statements in a self-assessment for student placement in an intensive english program. System, 80, 269-287.

doi:10.1016/j.system.2018.12.012

Talburt, S., \& Stewart, M. A. (1999). What's the subject of study abroad?: Race, gender, and "living culture". The Modern Language Journal, 83(2), 163-175. doi:10.1111/0026-7902.00013

Trofimovich, P., Isaacs, T., Kennedy, S., Saito, K., \& Crowther, D. (2016). Flawed self-assessment: Investigating self- and other-perception of second language speech. Bilingualism: Language and Cognition, 19(1), 122-140. doi:10.1017/S1366728914000832

van Compernolle, R. A. (2014). Sociocultural theory and L2 instructional pragmatics. Bristol: Multilingual Matters.

Vande Berg, M., Connor-Linton, J., \& Paige, R. M. (2009). The Georgetown Consortium Project: Interventions for student learning abroad. Frontiers: The Interdisciplinary Journal of Study Abroad, 18, 1-75.

Vande Berg, M., Quinn, M., \& Menyhart, C. (2012). An experiment in developmental teaching and learning: The Council on International Educational Exchange's seminar on living and learning abroad. In M. Vande Berg, R. M. Paige \& Lou, K. H. (Eds.), Student Learning Abroad: What Our Students Are Learning, What They're Not, and What We Can Do About It (pp. 383-407). Sterling, VA: Stylus Publishing, LLC

Vygotsky, L. S. (1978). Mind and society. Cambridge, MA: Harvard University Press. Wang, S., \& Vasquez, C. (2012). Web 2.0 and second language learning: What does the research tell us? CALICO Journal, 29(3), 412.

Williams, F., Chan, V., \& Cheung, H. (2009). The English language e-portfolio. In J. Zubizarreta. The learning portfolio: reflective practice for improving student learning, 2nd Ed. San Francisco: John WIley \& Sons, Inc. 